\title{
Great Miscalculation of David Cameron
}

\author{
V.N. Chepik
}

For citation: Chepik V.N. Great Miscalculation of David Cameron. Vestnik of Saint Petersburg University. History, 2018, vol. 63, issue 1, pp. 301-310. https://doi.org/10.21638/11701/spbu02.2018.119

This review essay focuses on the monograph of the British researcher A. Glenkross. It is devoted to the key topic in international discussions - Britain's exit from the EU. In view of a plenty of the literature appearing now concerning Brexit, A. Glenkross is one of the few scholars who analyzes its political reasons. As follows from the book, the main reasons which have led to the referendum on British membership in EU as well as to D.Cameron's defeat were, firstly, the results of 2015 UK General Elections. The vote revealed disagreements among British citizens. According to D. Cameron, after improving the terms of membership the referendum was to reconcile two opposing camps by the results of vote to which the minority would be compelled to obey. Secondly, different political traditions of Britain and the EU that delivered discomfort for the British political tradition and for the way of life. As a result, Britain tried to withdraw EU from closer integration towards federal union getting the nickname of «the strange partner». The author emphasizes that D. Cameron's negotiations with EU prior to the referendum were "the valiant final attempt to make it work for Britain, but for the majority of the British voters EU has not proved sufficient flexibility". Thirdly, the growth of political influence of Eurosceptics led to the vote on EU membership. Lack of reforms within EU which could be suited with the British played into the hands of Eurosceptics who claimed that the EU was unreformable and heading towards federal union. Fourthly, there was organized and well-funded opposition, namely, the Party of independence of the United Kingdom. In conclusion the author summarizes that David Cameron's gamble proved a great miscalculation with bad consequences for the UK domestic as well as foreign policy in the near future. He claims that for the settlement of constitutional issues a referendum as an element of direct democracy is not suitable.

Keywords: Brexit, great miscalculation, referendum, renegotiation, Common market.

\section{Великий просчет Дэвида Кэмерона}

\section{B. Н. Чепик}

Для цитирования: Chepik V.N. Great Miscalculation of David Cameron // Вестник Санкт-Петербургского университета. История. 2018. Т. 63. Вып. 1. С. 301-310. https://doi.org/10.21638/11701/ spbu02.2018.119

В статье анализируется работа британского исследователя А.Гленкросса. Она посвящена широко обсуждаемой в настоящее время не только в британской, но и мировой политике теме - выходу Великобритании из ЕС. Цель исследования - выявить при-

Chepik Victor N. - PhD, Senior Lecturer, Belorussian State Agricultural Academy, 11, Temiryazeva str., Gorky, Mogilev region, 213407, Belarus; e-mail: victor_chepik@mail.ru

Чепик Виктор Николаевич - канд. ист. наук, старший преподаватель, УО «Белорусская государственная сельскохозяйственная академия», Республика Беларусь, 213407, Могилевская обл., г. Горки, ул. Тимирязева, 11; victor_chepik@mail.ru

(C) Санкт-Петербургский государственный университет, 2018 
чины, которые привели Соединенное Королевство к брекситу, и оценить последствия брексита для внешней и внутренней политики Великобритании. В результате проведенного анализа можно сформулировать основные причины, которые привели к референдуму по вопросу о членстве в ЕС и поражению Д. Кэмерона. Ими стали, во-nервых, результаты выборов 2015 г. Они показали наличие разногласий между гражданами по вопросу членства в ЕС. Автор утверждает, что при помощи референдума Д. Кэмерон рассчитывал примирить два противоборствующих лагеря, сначала путем пересмотра условий членства, а затем результатами голосования на референдуме, которым будет вынуждено подчиниться меньшинство. Bo-вторых, сыграли свою роль разные политические традиции Британии и ЕС, что доставляло дискомфорт британской политической традиции и образу жизни. Как следствие, Британия пыталась увести ЕС от более тесной интеграции, за что и получила прозвище «странного партнера». Автор отмечает, что переговоры Д.Кэмерона с ЕС накануне референдума были «последней отважной попыткой заставить ЕС работать на Британию», но для большинства британских избирателей $\mathrm{EC}$ «не проявил достаточной гибкости». B-mpeтьих, возросло политическое влияние евроскептиков. Отсутствие реформ в ЕС, которые могли бы стать популярными среди британцев, играло на руку евроскептикам, которые утверждали, что ЕС нереформируем и «движется к федеративному союзу». $B$-четвертых, наличие организованной и хорошо финансируемой оппозиции в лице Партии независимости Соединенного Королевства. В заключение утверждается, что решение о референдуме оказалось великим просчетом Д.Кэмерона с тяжелыми последствиями как для внутренней, так и для внешней политики страны. Для решения таких важных вопросов, имеющих конституционное значение, референдум как элемент прямой демократии не пригоден.

Ключевые слова: брексит, великий просчет, референдум, пересмотр условий, Общий рынок.

In 2016, as part of Palgrave Pivot series - which allows for speedy dissemination of medium-size studies (around the length of three to six standard journal articles) a book on an important and sensitive topic, both for British and for world politics, was published in the UK. Its author, the British researcher, the senior lecturer of the chair of politics and international relations of Aston University, A. Glenkross prepared substantial, but not deprived of flaws the research within short limits of time. His book consists of six chapters. Unlike the majority of other researchers who considered mainly the social reasons of Brexit, A. Glenkross addresses political issues. Such as the renegotiation of the terms of British membership that preceded the vote on EU membership; the reasons which led to defeat of D. Cameron's government strategy and reflection on the "political philosophy of Brexit".

In the introduction, allocated as the separate chapter (Introduction: the Great Miscalculation) A. Glenkross formulates quite ambitious purposes for the project prepared in deadlines. In particular, "to shed light on how the United Kingdom came to vote for Brexit", and "to evaluate the implications that this decision has for the country's international relations as well as for its domestic politics" ${ }^{1}$.

It cannot be told for sure that the purposes were achieved to the full extent. As it seems, it is not possible to reach the objectives without a thorough investigation of governmental documents, but the author limits himself to the analyses of statistics, media

${ }^{1}$ Glencross A. Why the UK Voted for Brexit. David Cameron's Great Miscalculation. Birmingham (UK), 2016 (Ser. Palgrave Studies in European Union Politics). P. 2. 
reports and literature available at his disposal. Nevertheless, this work succeeds in carrying through a coherent message that combines interesting facts and conclusions, which could serve as a starting point for further research of integration processes in EU as well as political processes in Britain which resulted in the vote for Brexit.

A. Glenkross analyzes in every detail the circumstances which have compelled the British Prime Minister D. Cameron to put a question of EU membership on vote. The reason for Britain to vote on EU membership, as A. Glenkross states, was the $2015 \mathrm{UK}$ General Election that "set the stage for this momentous decision. For despite heralding a return to one-party majority government, that election revealed a country torn between exceptionalist identity claims"2.

The author fairly claims that D. Cameron plumped for holding a referendum in order to improve his chances at the ballot box and to reconcile factions within his party. Thus, Cameron has taken up the tactic which proved to be effective in 1975 referendum - "to attempt a reconciliation between two camps, first through renegotiation of the terms of EU membership" , and then, as follows from the book, through the results of voting on a referendum to which the minority would be compelled to obey.

A. Glenkross assumes that D. Cameron was confident of winning the referendum on the basis of a pragmatism and bean-counting evaluation. However, the public opinion "was out of step with the government cost - benefit argument" and "David Cameron's gamble proved a great miscalculation" 4 . The author ranks the 2016 referendum amongst the major political blunders of British Prime Ministers which caused shock waves across Europe and North Atlantic. The decision to delegate responsibility to the people ended up costing him his position as Prime Minister. EU heads of states and leaders of EU institutions were equally taken aback by this unprecedented reverse for European integration.

As follows from the text of the book, A. Glenkross agrees with the false opinion of the historian R. Granieri ${ }^{5}$, which regards the choice made by British voters as anti-EU, because "at no time has Britain actively sought to undermine an organization within which it was already a member"6. Moreover, he recognizes unexpectedness of the result for the academics because "there are no navigational charts for the course that now needs to be plotted".

However, as I can judge, the tendency for the EU leaving is traced from the analysis of an available literature. Here come only few examples. S. Walls specifies the growth of Eurosceptics influence within the Conservative party after "the Black Wednesday" (a sharp decrease in an exchange rate of pound on September, 16th 1992) ${ }^{7}$. After the 2010 Parliament elections the group of conservatives, supported by 40 million British citizens, put to the Parliament an offer of taking a referendum on EU membership ${ }^{8}$. In January 2013, D. Cameron declared that in the case of a victory in Parlimentary elections, he will

${ }^{2}$ Ibid.

3 Ibid. P. 17.

4 Ibid. P. 2.

${ }^{5}$ Granieri R. J. Special Relationships: The EU, Brexit, and the Atlantic Community. URL: http: // www. fpri.org/article/2016/06/ special-relationships-eu-brexit-atlantic-community (accessed 10.08.2017).

${ }^{6}$ Glencross A. Why the UK Voted for Brexit. David Cameron's Great Miscalculation. P. 2.

7 Wall S. A Stranger in Europe: Britain and the EU from Thatcher to Blair. Oxford, 2008. P .212.

8 EU referendum: Rebels lose vote in Commons // BBC News. http://www.bbc.co.uk/news/uk-politics-15425256 (accessed 10.08.2017). 
lead a referendum on EU membership 9 . (It was confirmed in the Conservative party election manifesto in $2015^{10}$.) Finally, the results of elections in the European Parliament in 2014 spoke for itself. The Eurosceptics from the UKIP won the majority of votes which confirms unpopularity of the pro-European course of the conservative party among vot$\mathrm{ers}^{11}$.

In the second chapter "The 40-Year "Neverendum" on the UK's Relationship with Europe" the author introduces the new notion of "Neverendum" for the characteristic of a continuity of the British Euroscepticism, since the first referendum in the Great Britain on EEC membership in 1975.

A. Glenkross highlights concept of "British exceptionalism" and confirms his argument by the UK refusal from euro, the Schengen agreement as well as by the determination to leave from the European ideal "of ever closer union"12. The author, contradicting his own statements regarding D. Cameron's great miscalculation by calling for a new vote on EU, which resulted in the decision for the Great Britain to leave the EU, writes that "the Britain's political economy also makes it stand out". He argues as follows. "Consistently large trade deficit of the Great Britain is compensated by equally large capital inflows. This means financial service - namely the City of London - are politically very influential and dominate the economic aspect of relations with the EU"13. The author's argument that the nature of British exceptionalism within the EU has no nationalist roots could be accepted with no dispute.

Addressing the roots of the British policy towards the European integration, the author demonstrates that in 1950s the Great Britain stayed aloof from the original Franco-German project for European unity. Unfortunately, his next historical reference is already related to the 1975 referendum on the British EEC membership. Thus, the author omits the important period when the bases of the British approach to the European political integration was formed. Documents of this period concerning the governmental course on the European political integration have been analyzed in detail by Russian-speaking researchers ${ }^{14}$. It shall presently be argued that the author attributes the UK determination to avoid closer union and to counteract the development of EU integration towards a federative state - to the forty-year period of activity of Eurosceptics mistakenly. A. Glenkross characterizes the British approach to the European integration by using the abstract

${ }^{9}$ David Cameron's EU speech // The Guardian. http://www.theguardian.com/politics/2013/jan/23/ david-cameron-eu-speech-referendum (accessed 10.08.2017).

${ }^{10}$ Conservative party manifesto 2015. Strong leadership. A clear economic plan. A brighter, more secure future // Amazone web service. URL: https://s3-eu-west-1.amazonaws.com/manifesto2015/ConservativeManifesto2015.pdf (accessed 10.08.2017).

${ }_{11}$ European Parliament Information Office in the United Kingdom. http://www.europarl.org.uk/en/ root.html (accessed 10.08.2017).

12 Glencros A. Why the UK Voted for Brexit. David Cameron's Great Miscalculation. . P. 8.

13 Ibid.

${ }^{14}$ Chepik V.N., Borisenko V.N. Problema zapadnoevropeiskoi integratsii v britanskoi vneshnei politike. Politicheskii i oboronitel'nyi aspekt (1961-1975). St. Petersburg, 2016. P. 160; Chepik V. N. Nemetskii faktor v britanskoi integratsionnoi politike (1961-1973) // Trudy kafedry istorii Novogo i noveishego vremeni. 2016. N 16 / comp. by T. N. Goncharova. P. 157-168; Baryshnikov V.N., Vozgrin V.E., Goncharova T.N., Evdokimova N. P., Klimova G. S., Sidorenko L. V., Sokolov O. V., Plenkov O. Iu., Fokin V.I. Ot natsional'nykh gosudarstv k edinoi Evrope: problemy evropeiskoi integratsii v XIX-XXI vv. St. Petersburg, 2016; Capitonova N. K., Romanova E. V. Istoriia britanskoi vneshnei politiki. Moscow, 2016; Lipkin M. A. Britaniia v poiskakh Evropy. Dolgii put’ v EES 1957-1974 gg. St. Petersburg, 2009. 
statement such as "a pragmatic and utilitarian foreign policy stripped of a normative commitment to a European ideal of ever closer union"15.

One of the benefits of work is that the author, among big number of referendums which took place in other EU countries on the European policy (about 50), managed to reveal the novelty of the British approach. A. Glencross examines similarities and differences between the 2016 and the 1975 referendums. He argues that the British position towards integration - something greater than the mainstream political trend (possibly, he means eurosceptics), was "not just nationalist populist as with the Front National in France", it was a position in which "the possibility of withdrawal from the EU" was "openly discussed and real readiness was expressed «to actually devolve this decision to the public vote" 16 .

A. Glenkross aknowledges that the idea to hold a referendum on EU membership penetrated all political spectrum and covered not only Eurosceptics from Conservative party, but also Laborers and Liberal democrats. While analyzing a position of Eurosceptics, the author emphasizes two important aspects, firstly, "the nature of EU membership is somehow unfair or too restrictive for the more free-trade and globally oriented UK". As a result, the UK had an opt-out from the most constraining aspect of integration, European Monetary Union and its tight fiscal coordination, secondly, "there was no national consent to membership in the political union as on the 1975 referendum British voted for a common market and not a political union" 17 .

However, the author fails to mention a traditional argument for the British Eurosceptics that Britain and EU diverge in political traditions. It was repeated in the speech of the new Prime Minister T. May, who replaced D. Cameron. "Unlike other European countries, we have no written constitution, but the principle of Parliamentary Sovereignty is the basis of our unwritten constitutional settlement. We have only a recent history of devolved governance - though it has rapidly embedded itself - and we have little history of coalition government". "The public expect to be able to hold their governments to account very directly and as a result supranational institutions as strong as those created by the European Union sit very uneasily in relation to our political history and way of life" 18 . As a consequence, Britain tried to withdraw EU from closer integration and at times have been seen as an awkward member state, explained T. May. According to her, David Cameron's negotiation was a "valiant final attempt to make it work for Britain" but "the blunt truth" was that "there was not enough flexibility on many important matters for a majority of British voters"19.

The author of the book successfully emphasizes the fact of ever-present debate in Europe concerning the spectre of a federal superstate. According to Glencross, the claims of Eurosceptics were reduced to the arguments that EUs institutional structure and its policy effects had evolved beyond the control of British voters since 1975. Therefore, Europhiles across the major political parties believed that the only way to settle this argument was by resorting to the voice of people ${ }^{20}$.

15 Glencross A. Why the UK Voted for Brexit. David Cameron's Great Miscalculation. P. 8.

16 Ibid. P. 10.

17 Ibid P.11.

18 May Theresa. The Plan for Britain. 2017. URL: https://www.gov.uk/government/speeches/the-governments-negotiating-objectives-for-exiting-the-eu-pm-speech (accessed 10.07.2017).

19 Ibid.

20 Ibid. P. 11. 
The success on elections in European Parliament of populist Party of Independence of the United Kingdom was connected in the book with the general negative perception of EU and the requirement to restrict immigration from other EU countries. The author accuses T.Blair's government of the scale of potential labour migration and chose not to impose transitional controls after the 2004 enlargement ${ }^{21}$. He mentions that even the Europhile wing in the Conservative Party recognized that enormous gains that the free movement of EU citizens offers, such as capital mobility and free labour movement, provides UK businesses with a vast pool of resources with which to innovate and grow, can be realized but only on the basis of accepting constrains on immigration policy. As it becomes known from the book, the Eurosceptics demanded unilateral concessions for the UK, such as parliamentary veto on European legislative procedure, as well as concessions on fundamental principles of EU, in particular, concerning free movement of EU citizens ${ }^{22}$.

A. Glencross believes that D. Cameron's tactics in 2016 - as with Labour in $1974-$ 1975 - was to attempt a reconciliation of two camps, first through renegotiation of terms of EU membership. The author makes a conclusion that the problem with that strategy was that, "as the referendum campaign eventually demonstrated, there is both little common ground between the two factions and not much scope for change within the EU system" ${ }^{23}$. The British media and political establishment were divided over the merits of integration. The most significant consequence of this ideological hostility was a persistent information deficit among British voters. The author vividly illustrates how much press deformed the facts by the fact that "citizens' median estimate for British contribution to the EU budget is $€ 40$ billion per annum, when the reality is $€ 11$ billion" 24 .

In the third chapter "Renegotiating Terms of EU Membership Prior to the Referendum" the author repeats the analysis of an internal political situation in the country. A. Glenkross argues about wide support from the British citizens of EU membership and confirms it with the results of regular polls $s^{25}$. On the other hand, the growth of influence of Eurosceptics is emphasized. The absence of reforms that could "gain popular traction" among British played into the hands of Eurosceptics who "rightly or wrongly peddled a message that the EU was "unreformable" and heading towards federal union". The strength, particularly in the print media, of EU criticism "not only drowned out the Europhile message, it also infected anti-EU sentiments". Such an environment was the perfect breeding ground for another feature not present in 1975: populist opposition to the EU mobilized in the form of an organized and well-funded Eurosceptic political party, namely UKIP ${ }^{26}$.

Criticizing D. Cameron for his decision to renegotiate the terms of membership, the author argues that "by 2015, British exceptionalism was deeply engrained within the EU system in a way that was not the case 40 years ago. With little fanfare and devoid of domestic public recognition, the UK has profoundly shaped EU development since the end of the Cold War the British exclusiveness has deeply taken roots in system of EU"27. Enlargement and expanded foreign policy powers were key British objectives, while in other key areas the UK benefited from a bespoke system of opt-outs (Schengen, i.e. the border-free

\footnotetext{
21 Ibid. P. 15.

22 Ibid. P. 17

${ }^{23}$ Ibid.

24 Ibid. P. 19.

25 Ibid. P. 22.

26 Ibid.

27 Ibid. P. 24.
} 
space, and the euro) and special treatment (e.g. the double majority voting system of the European Banking Authority). In these circumstances, there was little room for accommodating new demands, especially those that go against fundamental EU principles.

A. Glencross demonstrates that the objective of renegotiation of the UK membership terms was the necessity to conclude a new agreement with the European Council, but not leaving the EU. First of all, it was the UK attempt to do away with Britain's treaty commitment to "ever closer union", which meant for the Eurosceptics loss of the sovereignty and national identity ${ }^{28}$.

Another Cameron's demand was to allow national parliaments from across the EU to oppose EU legislation, a procedure known as a "red card". This proposal went beyond the existing "orange card procedure" that allows national parliaments to act in concert to challenge laws proposed by the European Commission. The "red card" proposal was firstly announced by the British in Germany in 2013. Not long after Conservative MPs wrote to the Prime Minister asking for the introduction of a unilateral British parliamentary veto over EU legislation.

The grudging acceptance that a unilateral opt-out from unwanted single market legislation is impossible explains why getting the $\mathrm{EU}$ to focus on economic competitiveness was another Cameron priority. The UK government went into the renegotiation harbouring a legitimate concern that the Eurozone may act as a block within the EU, using its majority in the EU Council to pass laws, primarily for its own interests. As a result, financial regulations could be imposed on the City making it less globally competitive, thereby hurting a key UK economic interest. Lastly, there were the demands surrounding individual rights. This is because the right of EU citizens to move to the UK became inherently politicized as part of a broader debate over immigration - a subject absent from the 1975 EEC referendum. The author reported that the Great Britain denied access to in-work benefits to recently arrived jobseekers from elsewhere in the EU, despite it was discriminatory. The rules oblige UK workers to have contributed for a number of years prior to claiming benefits. As a result, D. Cameron needed to avoid a stalemate and to proclaim a substantive victory, however result would depend on the response from other EU capitals.

A. Glencross states that on a strategic level, UK's withdrawal from the EU has a number of important ramifications, many of them potentially favourable to French interests. France's permanent UN Security Council seat could gain a new legitimacy as the voice of the EU on the international stage. The absence of a British presence in the EU's decision-making bodies would make trade and regulation policy more protectionist in line with the instincts of French governments of both Left and Right. Lastly, a British departure would make the Franco-German tandem once again the be-all and end-all of European integration. Brexit could in fact breathe new life into this stalled alliance by creating momentum for a new EU initiative as a show of defiance to British Euroscepticism. But reticence of the French President 's to discuss Brexit is not attributed to ideological hostility by the author. Rather, the cause lay in France's twin economic and political weakness, which "hampers its ability to guide the future course of European integration" 29 .

The author analyzes in detail the results of renegotiation of the terms of Britain membership in the EU which "passed under trusteeship of A. Merkel" and "has not justified the British government expectations". A. Merkel confirmed the red lines: "there could be

28 Ibid. P. 25.

${ }^{29}$ Ibid. P. 28. 
no concessions involving quantitative restriction on EU migration" or "loosening UK application of single market regulation" ${ }^{30}$. Instead of rolling back the principle of free movement of EU citizens, the UK government had to be content with technical tweaks of welfare provisions for migrants and some emollient pledges for how the EU would be run in the future.

Nevertheless, as follows from the analysis of results featured in the book, D. Cameron managed to get some concessions and changes in all the issues which were put under negotiation. Therefore, Britain could confirm its special status in the EU. As follows from the book, one of the main issues - migration from the EU countries, which displeased Eurosceptics, has been partially settled. As a consequence, the Great Britain would have become less attractive to emigration (due to reduction of social benefits and grants for "recent immigrants"). The pledges of the European Counsel not to apply to the Great Britain the statement of EU movement to ever-closer union should be attributed to D. Cameron's achievements $^{31}$. The president of European Counsel Jean-Claude Junker has confirmed that "the concept of ever-closer union allows for different paths of integration for different countries" 32 .

The EU has also accepted the procedure known as "a red card" which allowed rejecting the EU legislation if it goes against the will of the majority of national parliaments. Britain has also preserved the right to carry out supervision of its own financial sector. The EU Council has promised to give priority of a competition, including reductions in burdensome EU regulations and rules. To prove the author' statement it would be pertinent to give an example from the British government White Paper. It says as follows. "The sovereignty of Parliament is a fundamental principal of the UK constitution. Whilst Parliament has remained sovereign throughout our membership of the EU, it has not always felt like that. The extent of EU activity relevant to the UK can be demonstrated by the fact that 1, 056 EU-related documents were deposited for parliamentary scrutiny in 2016. These include proposals for EU Directives, Regulations, Decisions and Recommendations, as well as Commission delegated acts, and other documents such as Commission Communications, Reports and Opinions submitted to the Council, Court of Auditors Reports and more" 33 .

In the fourth chapter "The EU Referendum Campaign" the author characterizes D. Cameron's tactic which proved to be effective in 1975 referendum. At that time the British government emphasized economic gains from EEC membership. However, in the new conditions to the UK in 2016 the tactic proved to be "the great miscalculation". Despite the fact that polls demonstrated positive attitudes of voters towards staying in a reformed EU, the government misjudged the public mood regarding both immigration and trust in ruling elites. The other "more forgivable error of judgment concerned underestimating the opportunism of certain Conservative cabinet ministers" due to the fact that 6 ministers of the government voted to leave EU.

Thus, as follows from the monograph, the reasons for D. Cameron's defeat on referendum were firstly, the absence of EU reforms that would become popular with the

${ }^{30}$ Ibid. P. 29.

31 Ibid. P. 38.

32 Ibid. P. 25.

33 WHITE PAPER on The United Kingdoms exit from and new partnership with the European Union. February 2017, p.77. URL: https: //www.gov.uk/government/publications (accessed 10.08.2017). 
British and would enable Eurosceptics to claim that EU was unreformed and was moving to a federative superstate. Secondly, severe criticism from mass media which not only drowned the statements of Europhiles, but also heated the anti-European moods due to manipulation by the facts. Thirdly, the presence of the organized and well-funded political opposition in the form of the Party of independence of the United Kingdom so that there was a merge of nationalist Euroscepticism with anti-elites mood.

In the fifth chapter "The unfinished business of Brexit" consequences of voting for leaving EU are considered. The author analyzes two most challenging issues for the Great Britain. First, how to preserve access to privileged trading terms with the Common Market, while not being a member of EU. Second, how to preserve Britain as a single state as Scotland did not vote to leave the $\mathrm{EU}$ and did not want to leave the $\mathrm{EU}^{34}$.

According to the author, most challenging of all is what to do about participation in the single market - the location for half of UK trade and a magnet for foreign investment. Complete withdrawal from this market is self-destructive. $90 \%$ of UK exports by value would become subject to EU tariffs. The UK would need to negotiate its own "schedule" of tariffs and subsidies - a process requiring the formal consent of the other WTO members. Brexit necessitates the crafting of a new multilateral arrangement with European trade partners or else a series of bilateral deals. New trade treaties are a matter of urgency as leaving the EU means breaking with the 53 countries that have negotiated a free trade agreement with it. However, it is not conceivable for the UK to complete new trade deals until it has formally left the EU and clarified its terms of access to the single market ${ }^{35}$.

But at the same time as Parliament and political parties in Westminster address the international ramifications of the Brexit referendum, there is a simultaneous domestic constitutional crisis to resolve as the vote on referendum brought to the fore once again the issue of Scottish independence. The future of Northern Ireland is also not certain as the majority of its population has voted against leaving the EU. However, to answer these questions authentically could be possible only by analyzing governmental documents on political strategy as well as final results of negotiations with EU regarding terms of the UK leaving. In 2017 the government stated its position in two White Papers and reports on the preliminary results of negotiations by the government members.

In the final chapter "Rousseau's Revenge: The Political Philosophy of Brexit" the author managed to show that at present the ideal model of a political system to protect interests of all the citizens in a society and eliminate a social inequality does not exist. The model of an ideal political system still should be developed. According to the author, the post-democratic period is characterized by a political inequality which D. Cameron has tried to overcome, having resorted to an element of direct democracy - a referendum. However, for the settlement of constitutional issues a referendum is not suitable.

On the whole, despite the fact that some of the author's observations have become obsolete in the result of the pace of developments since the book's publication, the research by A. Glencross remains an important and historically sensitive account of this political event which proved to be decisive for the domestic as well as foreign policy of the UK.

34 Glencross A. Why the UK Voted for Brexit. David Cameron's Great Miscalculation. P. 47.
35 Ibid. P. 48. 


\section{References}

Baryshnikov V.N., Vozgrin V.E., Goncharova T.N., Evdokimova N.P., Klimova G.S., Sidorenko L.V., Sokolov O. V., Plenkov O. Iu., Fokin V.I. Ot natsional'nykh gosudarstv $k$ edinoi Evrope: problemy evropeiskoi integratsii $v$ XIX-XXI vv. Issues of European Integration in the 19-21 $11^{\text {st }}$ centuries. St. Petersburg, RCHA Publ., 2016, 620 p. (In Russian).

Capitonova N.K., Romanova E.V. Istoriia britanskoi vneshnei politiki. Moscow, International Relations Press, 2016, 840 p. (In Russian).

Chepik V.N. Nemetskii faktor v britanskoi integratsionnoi politike (1961-1973). Trudy kafedry istorii Novogo i noveishego vremeni, 2016, no. 16, comp. by T. N. Goncharova, pp. 157-168. (In Russian).

Chepik V. N., Borisenko V. N. Problema zapadnoevropeiskoi integratsii v britanskoi vneshnei politike. Politicheskii i oboronitel'nyi aspekt (1961-1975). St. Petersburg, RHGA Publ., 2016, 160 p. (In Russian).

Glencross A. Why the UK Voted for Brexit. David Cameron's Great Miscalculation. Birmingham (UK), Springer Publ., xi + 84 p. (ser. Palgrave Studies in European Union Politics).

Granieri R. J. Special Relationships: The EU, Brexit, and the Atlantic Community. 2016. URL: http: // www. fpri.org/article/2016/06/ special-relationships-eu-brexit-atlantic-community (accessed 10.08.2017).

Lipkin M. A. Britaniia v poiskakh Evropy. Dolgii put'v EES 1957-1974 gg. St. Petersburg, Alteiia Publ., 2009, 239 p. (In Russian).

Wall S. A. Stranger in Europe: Britain and the EU from Thatcher to Blair. Oxford, Oxford University Press, 2008, $246 \mathrm{p}$.

Waterfield B. David Cameron fails to rally EU governments behind Brussels spending cut. The Daily Telegraph. URL: http://www.telegraph.co.uk/news/worldnews/europe/eu/8174313/David-Cameron-failsto-rally-EU-governments-behind-Brussels-spending-cut.html (accessed 31.10.2016).

Waterfield B.David Cameron will back down in fight with EU, say officials. The Daily Telegraph. http:// www.telegraph.co.uk/news/politics/david-cameron/7861400/David-Cameron-will-back-down-infight-with-EU-say-officials.html (accessed 31.10.2016).

Watt N., Siddique H. David Cameron and Nick Clegg set out key policy plans. The Guardian. URL: http:// www.theguardian.com/politics/2010/may/12/cameron-clegg-set-out-policies (accessed 20.12.2016).

Wells M. David Cameron rules out transfer of powers to strengthen Eurozone. The Guardian. URL: http:// www.theguardian.com/politics/2010/may/21/cameron-merkel-euro-greece (accessed 20.12.2016).

Received: 01.10.2017

Accepted: 28.12.2017 